Phelps, J., Dermawan, A., Garmendia, E. 2017. Institutionalizing environmental valuation into policy: Lessons from 7 Indonesian agencies. Global Environmental Change 43:15-25. http://dx.doi.org/10.1016/j.gloenvcha.2017.01.004

\title{
Institutionalizing environmental valuation into policy: Lessons from 7 Indonesian agencies
} Jacob Phelps ${ }^{1,2 *}$, Ahmad Dermawan ${ }^{2,3}$, Eneko Garmendia ${ }^{4,5}$

${ }^{1}$ Lancaster Environment Center, Lancaster University, Lancaster, Lancashire LA1 4YQ, United Kingdom

${ }^{2}$ Center for International Forestry Research (CIFOR), Jalan CIFOR, Situ Gede, Bogor Barat, 16115, Indonesia

${ }^{3}$ Public Administration and Policy, Wageningen University, Hollandseweg 1, 6700 EW, Wageningen, Netherlands

${ }^{4}$ Department of Applied Economics I, University of the Basque Country, UPV/EHU, Vitoria-Gasteiz, Spain

${ }^{5}$ Basque Centre for Climate Change (BC3), Leioa, Spain. jacob.phelps@gmail.com

Keywords: ecosystem services, environmental governance, science-policy interface, green economy, values, commoditization

\begin{abstract}
Monetary valuation of the environment is increasingly embedded in policy. Despite broad claims that valuation is policy-relevant, there is widespread frustration that it has not widely improved environmental outcomes, that it obscures many other types of values, and presents unintended consequences. We argue that this is, in part, because of a tendency to overlook the mechanics of how valuation tools and data are embedded into the institutions (regulations, norms, rules, schemes) that mediate decision-making. Discussions of how valuation engages with policy are often anecdotal and rarely systematic. This manuscript responds with a structured analysis of valuation within 7 Indonesian government institutions. By analyzing the legislative provisions that deal with valuation within each agency, we explore the challenges of institutionalizing valuation into policy. We consider the difficulties of: defining what is (and isn't) valuable, specifying methods, and identifying policy objectives. We found broad gaps and inconsistencies in the aims, definitions, methods, and treatment of non-market goods and services. and identify a need for broadened thinking about the role of valuation data within everyday environmental governance, including how it is codified and operationalized. To this end, we provide a framework of the "cascade" relationship between environmental management, ecosystem goods and services, human wellbeing, and their relationship to environmental governance, which uncovers the mechanics of how valuation can inform decision-making via different institutional arrangements. We call for a critical, yet also more pragmatic and fieldbased interrogation, of how and why valuation is conducted by decision-makers, in order to improve our understanding of its social and environmental implications.
\end{abstract}




\section{Introduction}

There are growing efforts to better account for ecosystem goods and services in decision-making (Costanza et al. 1997; Ricketts et al. 2014; Bateman et al. 2015). While there are many ways of thinking about values and environmental benefits (Diaz et al. 2015; Chan et al. 2016), these efforts, while covering a wide range of goods and services, often emphasize monetary valuation, and incorporate different accounting perspectives that include private, global, national and subnational goods (Pearce et al. 1987; Costanza and Daily 1992; Guerry et al. 2015). Such environmental valuation translates environmental benefits into the standard monetary language in which decisions and trade-offs are commonly understood (TEEB 2010; Costanza et al. 2014).

Valuation is embedded across environmental policies and platforms, often in the form of natural capital valuation, trade-off analyses, green accounting and payment for ecosystem service schemes (overviews in Gómez-Baggethun and Pérez-Ruiz 2011; Braat and de Groot 2012). Contemporary efforts include multilateral initiatives, such as The Millennium Ecosystem Assessment (MEA 2006), The Economics of Ecosystems and Biodiversity (TEEB 2014), the World Bank's Wealth Accounting and the Valuation of Ecosystem Services partnership (WAVES 2015) and policies for Reducing Emissions from Deforestation and Forest Degradation (REDD+). To date, at least 69 countries have committed to accounting their natural capital stocks under WAVES, and in the United States, this is now a mandatory part of federal planning and decision-making (USA 2015). Private sector efforts are also mainstreaming valuation, including through the Natural Capital Declaration (2012) and World Business Council for Sustainable Development (WBCSD 2011). Valuation tools are further expanding with the adoption of "green economy" policies in many places, including tropical developing countries, which seek to promote growth in ways that also enable environmental protection and emissions reductions (Ferraro et al. 2012; Graat and de Groot 2012; e.g., Sills et al. 2014; WAVES 2015; UNCEP \& UNORCID 2015).

Considerable research has conceptualized, quantified, modeled and valued ecosystem goods and services (e.g., Hussai and Gundimeda 2010; TEEB, 2010; Costanza et al. 2014; Naeem et al. 2015), and parallel efforts have sought to facilitate the use of valuation data in decision-making (e.g., Rosenthal et al. 2014; Waite et al. 2014; InVest, www.naturalcapitalproject.org/INVEST; ARIES, www.airesonlines.org). A concurrent critical literature has interrogated the relative merits and limitations of valuation (e.g., Garmendia and Pascual 2013; Adams 2014; Spash 2015; Scharks and Masuda 2016), and the consequences of environmental commodification (e.g., McAfee 1999, 2015; Salzman and Ruhl 2000; McCauley 2006; Gómez-Baggethun and Pérez-Ruiz 2011; Robertson and Wainwright 2015).

There is, however, little structured analysis on the state of monetary valuation within everyday environmental governance processes. Despite broad claims that valuation data is policy-relevant, there is little evidence that it has been mainstreamed into environmental decision-making (see Kushner et al. 2012; Laurans et al. 2013; Waite et al. 2014; Laurans and Mermet 2014). This reflects disconnects between both academe and practice (cf. Laurans et al. 2014) and between environmental economics and political ecology (cf. Kallis et al. 2013; Kull et al. 2015). These disconnects run the risk of "tragedy of well-intentioned valuation", in which valuation technologies ultimately compromise desired outcomes (Gómez-Baggethun and Pérez-Ruiz 2011; 
e.g., biodiversity offsets, Maron et al. 2015 and green infrastructure, Garmendia et al. 2016). This has triggered growing demand for valuation to demonstrate more tangible outcomes (e.g., Pearce et al. 1989; Daily et al. 2009; Muradian and Rival 2012; Guerry et al. 2015; Silverton 2015), as well as for greater critical reflection of valuation tools (Gómez-Baggethun and Pérez-Ruiz 2011; Garmendia and Pascual 2013).

We contend that frustration with monetary valuation tools emerges, in part, because of a tendency to overlook the mechanics of how valuation is embedded into the institutions that mediate environmental management. Institutions include the "conventions, norms and legal rules of a society [that] provide expectations, stability and meaning essential to human existence and coordination, [and which] regularize life, support values and protect and produce interests" (Vatn 2006). This manuscript specifically considers government institutions interested in forests, and highlights legislation as one window, of many, for understanding how valuation is used by decision-makers. We apply this to Indonesia, a country at the center of discussions on forest governance, and consider 7 national agencies engaged in valuation. By taking stock of the legislation which refers to monetary valuation in these agencies, this manuscript identifies: the stated objectives for conducting valuation, the ecosystem goods and services valued, and the economic methods employed. It highlights key challenges to institutionalizing valuation into policy.

\section{Monetary valuation and environmental governance}

The relationships between environmental management, ecosystem goods and services, and human wellbeing are often envisioned as a "cascade" (de Groot et al. 2010; Fig. 1), in which there are multiple interplays between ecosystem-derived benefits and human decisions. There is a need to unpack the related decision-making processes. Notably, monetary valuation tools and data are often assumed to help inform and mediate these decisions, but there is a risk in assuming that valuation will automatically inform or improve decision-making (see Carpenter et al. 2009; Bille et al. 2012; Jordan and Russel 2014; Adams 2014). There is a need to examine the pathways through which valuation is expected to have influence (Fig. 1).

Valuation has a number of possible policy applications. It can advance general understanding of the environment, provide data to support individual decisions (e.g., landuse allocations), and support negotiations among stakeholders with distinct interest in different resource management plants (Clark et al. 2011) - all decisions that vary across spatial and temporal scales, in their data demands and the communities they engage (Hein et al. 2006; Bille et al. 2012; Costanza et al. 2014; Kelemen et al. 2015).

Valuation data may be used in decentralized, voluntary and/or private arrangements; for example to inform payments for ecosystem services schemes (PES) by translating specific services into monetary values (Ferraro and Kiss 2002). Valuation can also be institutionalized where individuals or corporate actors voluntarily internalize environmental values into decision-making, both through informal actions (e.g., desire to buy sustainable products) and through formal commitments (e.g., environmental certification, e.g., Kareiva et al. 2015). 
Valuation can also be embedded in government agencies. For example, it may inform deliberative multi-stakeholder processes to negotiate priorities and management options (Etxano et al. 2015). Valuation can also become formally institutionalized through legislation, such as to uphold environmental standards, with the monetary values of goods and services manifested as disincentives associated with noncompliance (e.g., fines), or incentives associated with compliance (e.g., subsidies) (Muradian and Gómez-Baggethun 2013). Valuation can also serve to measure damages in civil liability suits for environmental damage (e.g., due to pollution or forest destruction, e.g. Loureiro et al. 2009).

Engaging with valuation data involves a range of decisions that are often taken as implicit (Fig. 1, italics). These include technical and political decisions about which goods and services are valued, how they are valued, and how they are used. While these decisions can be mediated by a number of different institutional arrangements (Fig. 1), many natural resources, decision-making processes and related technologies are vested in government agencies, which are the focus of this manuscript. 


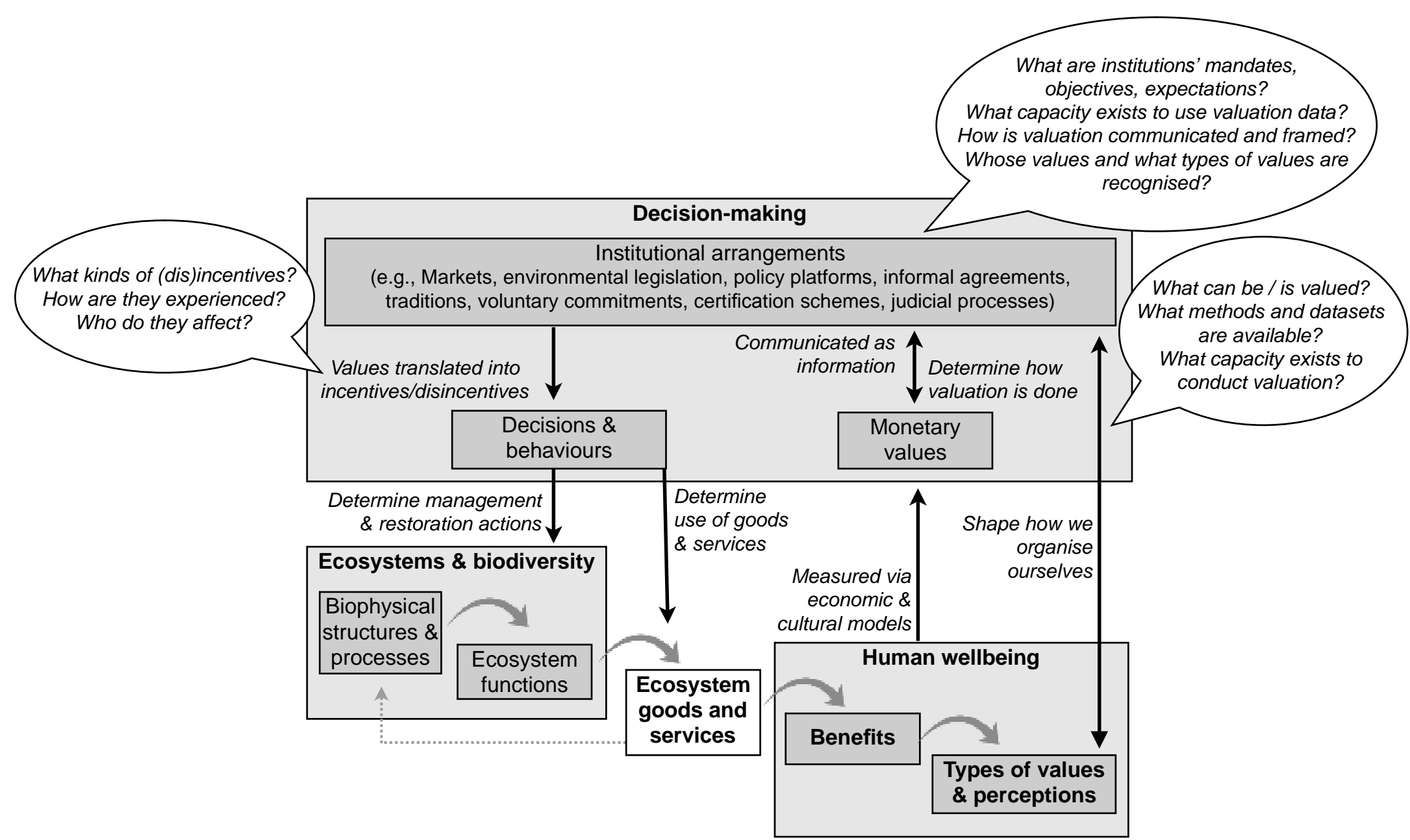

Figure 1. Framework showing the relationship between the "cascade" of environmental management, ecosystem goods and services, human wellbeing, and their relationship to environmental governance, highlighting the mechanics of how environmental valuation data can inform decision-making via different institutional arrangements. Italics indicate key questions to consider when institutionalizing valuation into decisionmaking. Based on the TEEB model (de Groot et al. 2010) and the model of ecosystem services and decision-making (Daily et al. 2009). 


\section{Methods}

\subsection{Indonesian case: A national focus on valuation}

Indonesia provides a key example of where valuation is increasingly central to environmental governance. Its rich natural capital stocks are an essential part of the national economy. Recent estimates suggest that more than $74 \%$ of Indonesia's poor depend directly on ecosystem services to fulfill basic livelihood needs, and that $76 \%$ of rural households derive income from forests and related services (UNEP and UNORCID 2015). However, Indonesia is experiencing rapid environmental change, resulting in huge economic losses (e.g., HRW 2009; BPK 2013; MAPPI 2012).

As a result, Indonesia is attracting significant efforts to translate ecosystem goods and services into monetary values, to promote conservation, measure losses in cases where damage has occurred, and strengthen decision-making to enable more sustainable "green" economic pathways (e.g., see Anderson et al. 2016). The country hosts a number of PES schemes for watershed services (Leimona et al. 2015), and is central to PES schemes for Reducing Emissions from Deforestation and forest Degradation (REDD+) to protect forest carbons tocks (Sills et al. 2014; Irawan et al. 2014). Indonesia is a new member of the WAVES Partnership, led by the World Bank, to promote "sustainable development by ensuring natural resources are mainstreamed in development planning and national economic accounts" (WAVES 2015). In parallel, a United Nations-supported environmental valuation exercise has been exploring valuation strategies to promote "policies necessary to transition to a green economy in Indonesia" (UNEP and UNORCID 2015). The Indonesian Ministry of Finance is also pioneering a new law on State Assets, which is likely to incorporate natural capital stocks into the national accounts.

\subsection{Focus on environmental legislation}

The institutionalization of valuation within state bureaucracy is evident in a number of different ways, including in budget allocations, strategic priorities, public statements, the perceptions of staff and management, and on-the-ground actions. We focus specifically on how valuation is treated in national legislation.

Legislation is central to formal organizations (see Hull 2012), and the codification of methods and data into legislation establishes frameworks that help guide action at different scales (see Fig. 1; Cowan and Foray 1997; Muradian and Gómez-Baggethun 2013). This is particularly important in the context of jurisdictional ambiguity and inter-agency conflicts (e.g., in Indonesia, Sahide and Giessen 2015). Unlike voluntary, individual or project-level actions (e.g., sustainability commitments, PES), state legislation mandates standards and contracts of accountability, even if it does not always reflect practices on-the-ground (McCarthy et al. 2012 Anderson et al. 2016). Legislation is also useful because it provides tangible, specific objects of study (see Hull 2012). It is thus of immediate interest as a bureaucratic tool that defines "(1) who and in what capacity [valuation data] should be considered during decisionmaking, and (2) what is considered relevant data and how that data is to be handled" (Vatn 2005). Legislation can also affirm "specific ideologies and techniques of socioecological organization" (loris 2015), espousing specific types of values, assumptions and choices (cf. Gasparatos 2010), including with regard to specific processes, actors and priorities (e.g., Salzman and Rhul 2000; Bille et al. 2012; Waite et al. 2014; cf. Rosenthal et al. 2014).

We collected national-level legislation, including both primary (usually national laws) and subsidiary legislation such as guidelines, regulations and decrees that make 
specific reference to environment valuation methods and data (Table 1). These were identified via the www.hukumonline.com database, and in discussions with experts in Indonesia from the Center for International Forestry Research (CIFOR), World Bank, Ministry of Environment, and UN Office for REDD+ Coordination in Indonesia. A 2-day focus group held at CIFOR in Bogor, Indonesia (see Phelps et al. 2014), also engaged 10 domestic agencies and civil society groups to identify legislation. This was either collected online or, where only hardcopies were available, from agency offices.

Legislation was included if it discussed monetary value, regardless of its accounting approach. The dataset included primary legislation, which grants agency mandates to pursue certain roles, but rarely includes details about valuation. Subsidiary Ministerial-level legislation and guidelines tend to include greater details on methods, data and the objectives of valuation (see Table 1). Where available, we also drew on supporting documents (reports, press releases, presentations, focus group) to more fully interpret pieces of legislation (Appendix). Energy, mineral and fisheries resources were excluded due to the particular complexities of the related legislation, and our focus on forest ecosystems.

For each agency, we identified (1) the goods and services valued, (2) how each was defined, and (3) the valuation methods used. We grouped legislation as covering six categories of goods and services (Table 3 ) that reflect those used in the legislation (rather than other, established ways of grouping ecosystem services, e.g., MEA 2005). Using an iterative process, we characterized their policy objectives for using valuation data (Table 2; see Appendix). 
Table 1. Indonesian national agencies involved in ES valuation and related legislation

\begin{tabular}{|c|c|c|}
\hline Agency & $\begin{array}{l}\text { Primary legislation granting mandate to conduct } \\
\text { valuation }\end{array}$ & Subsidiary legislation or document providing specific valuation methods \\
\hline $\begin{array}{l}\text { Ministry of } \\
\text { Finance }\end{array}$ & - Law no. 17 of 2003 on State finance & $\begin{array}{l}\text { - Directorate General of State Asset. Guidelines for valuation of natural resources: Valuation of } \\
\text { forestry and estate crops (2008). } \\
\text { - Directorate General of State Asset Regulation no. PER02/KN/2011 on Technical guidelines for the } \\
\text { valuation of assets under the state control in the form of natural resources. } \\
\text { - Directorate General of State Asset Regulation no. PER10/KN/2012 on Guidelines for valuation of } \\
\text { production forest } \\
\text { - Ministry of Finance Regulation no. } 98 \text { of } 2010 \text { on Valuation of assets under the state control in the } \\
\text { form of natural resources }\end{array}$ \\
\hline $\begin{array}{l}\text { Ministry of } \\
\text { Environment }\end{array}$ & $\begin{array}{l}\text { - Law no. } 32 \text { of } 2009 \text { on Environmental } \\
\text { protection and management }\end{array}$ & $\begin{array}{l}\text { - Ministry of Environment Regulation 7/2014 on Environmental loss due to pollution and } \\
\text { environmental damages } \\
\text { - Ministry of Environment Regulation number } 14 \text { of } 2012 \text { on Economic Valuation on Peat land } \\
\text { Ecosystem } \\
\text { - Ministry of Environment Regulation number } 15 \text { year } 2012 \text { on the Economic Valuation Guidelines on } \\
\text { Forest Ecosystem }\end{array}$ \\
\hline $\begin{array}{l}\text { Forest } \\
\text { Department }\end{array}$ & $\begin{array}{l}\text { - Law no. } 41 \text { of } 1999 \text { on Forestry } \\
\text { - Government Regulation no. } 12 \text { of } 2014 \text { on } \\
\text { Non-tax state revenues applicable at the } \\
\text { Ministry of Forestry }\end{array}$ & $\begin{array}{l}\text { - Ministry of Forestry Regulation no. 68/Menhut-II/2014 on Determination of reference prices to } \\
\text { calculate forest resource rent provision, compensation of tree stand, and replacement of tree stand } \\
\text { value }\end{array}$ \\
\hline $\begin{array}{l}\text { Supreme Audit } \\
\text { Agency (BPK) }\end{array}$ & - Law no. 15 of 2006 on Supreme Audit Agency & - Refers to ministerial guidelines \\
\hline $\begin{array}{l}\text { Board of } \\
\text { Finance and } \\
\text { Development } \\
\text { Supervision } \\
\text { (BPKP) }\end{array}$ & $\begin{array}{l}\text { - Presidential Regulation no. } 192 \text { of } 2014 \text { on the } \\
\text { Internal State Auditor }\end{array}$ & - Refers to ministerial guidelines \\
\hline $\begin{array}{l}\text { Central } \\
\text { Statistical } \\
\text { Agency (BPS) }^{* *}\end{array}$ & - Law no. 16 of 1997 on Statistics & $\begin{array}{l}\text { - Central Statistical Agency. Integrated system of environment and economic balance sheet } \\
\text { (Sisnerling) 2008-2012. (2013), focused on mineral, energy and forest sectors. }\end{array}$ \\
\hline $\begin{array}{l}\text { Ministry of } \\
\text { National } \\
\text { Development } \\
\text { Planning } \\
\text { (BAPPENAS) }^{* *}\end{array}$ & $\begin{array}{l}\text { Law no. } 25 \text { of } 2004 \text { on National development } \\
\text { planning system } \\
\text { - Presidential Regulation } 2 \text { of } 2015 \text { on Medium } \\
\text { term planning 2015-2019 }\end{array}$ & $\begin{array}{l}\text { - Refers to individual ministerial regulations. In collaboration with the WAVES programme, initial } \\
\text { focus is accounts of land banks, with a feasibility assessment of water resources. }\end{array}$ \\
\hline
\end{tabular}




\section{Results}

\subsection{Agencies and objectives for valuation}

The review highlighted that valuation is used across a broad range of national agencies, ranging from the Forest Department to state auditors (Table 1). These have distinct policy objectives (Table 2). These are generally weakly defined, but include widely recognized uses such as awareness-raising and specific policy analyses (cf. Costanza et al. 2014), as well as less-commonly recognized uses, including taxation and compensation.

- Raising awareness and interest: Valuation of goods and services to demonstrate their value and justify their protection or sustainable management decisions.

- National income and well-being accounts: Valuation of goods and services, usually referred to as natural capital stocks, at a somewhat generic, national-level and linked to international environmental accounting efforts. These do not identify specific policy applications, with the exception of audits of state finances, where natural resources are recognized as state assets and are therefore subject to financial oversight.

- Specific policy analyses: These more situation-specific processes seek to use valuation to inform more specific spatial and land-use planning decisions at the national and subnational levels.

- Taxation of forest-based goods and services: Indonesia has long collected taxes for timber harvest, as well as mandated contributions to a national reforestation fund. Tax collection has recently been extended to include a broader range of revenue-generating goods and services from the forest sector.

- Compensation in legal suits for environmental harm: Where environmental damage results in liability suits that result in financial compensation to the state or individuals, valuation can be used to measure damages. 
Table 2. Agency objectives for conducting environmental valuation, based on their primary and subsidiary legislation

\begin{tabular}{|c|c|c|}
\hline Agency & Type(s) of use & Principle objective(s) \\
\hline Ministry of Finance & $\begin{array}{l}\text { National income and well- } \\
\text { being accounts }\end{array}$ & $\begin{array}{l}\text { Valuation of natural resources that are recognized as state assets to contribute to a future national } \\
\text { natural resource balance sheet. }\end{array}$ \\
\hline Ministry of Environment & $\begin{array}{l}\text { Compensation } \\
\text { Raising awareness and } \\
\text { interest } \\
\text { Specific policy analyses } \\
\end{array}$ & $\begin{array}{l}\text { Valuation of damages to inform civil proceedings and out-of-court dispute resolution. } \\
\text { Valuation of forest, and specifically peatland ecosystems, to help managers understand the } \\
\text { importance of conservation and to inform spatial planning. }\end{array}$ \\
\hline Ministry of Forestry ${ }^{*}$ & Taxation & Valuation to inform collecting a wide range of state revenues from forests. \\
\hline $\begin{array}{l}\text { Supreme Audit Agency } \\
(\mathrm{BPK})^{* *}\end{array}$ & $\begin{array}{l}\text { National income and well- } \\
\text { being accounts } \\
\text { Compensation }\end{array}$ & $\begin{array}{l}\text { Valuation as part of financial audits to determine whether public money is collected and expended } \\
\text { in accordance with the existing laws and regulations. } \\
\text { Where there is evidence of misappropriation or corruption resulting in financial losses to the state, } \\
\text { the auditor is responsible for calculating these losses to inform compensation to the state. }\end{array}$ \\
\hline \multirow{2}{*}{$\begin{array}{l}\text { Board of Finance and } \\
\text { Development } \\
\text { Supervision }(\mathrm{BPKP})^{* *}\end{array}$} & $\begin{array}{l}\text { National income and well- } \\
\text { being accounts }\end{array}$ & $\begin{array}{l}\text { Valuation as part of financial audits to determine whether public money is collected and expended } \\
\text { in accordance with the existing laws and regulations. }\end{array}$ \\
\hline & Compensation & $\begin{array}{l}\text { Where there is evidence of misappropriation or corruption resulting in financial losses to the state, } \\
\text { the auditor is responsible for calculating these losses to inform compensation to the state. }\end{array}$ \\
\hline $\begin{array}{l}\text { Central Bureau of } \\
\text { Statistics (BPS) }\end{array}$ & $\begin{array}{l}\text { Raising awareness and } \\
\text { interest } \\
\text { National income and well- } \\
\text { being accounts }\end{array}$ & Valuation to provide the government and public with data on environmental statistics. \\
\hline $\begin{array}{l}\text { Ministry of National } \\
\text { Development Planning } \\
\text { (BAPPENAS) }\end{array}$ & $\begin{array}{l}\text { National income and well- } \\
\text { being accounts } \\
\text { Specific policy analyses }\end{array}$ & $\begin{array}{l}\text { Valuation to inform national development planning, across sectors and agencies, with a focus on } \\
\text { economic development in the forestry sector. }\end{array}$ \\
\hline $\begin{array}{l}\text { The Ministry of Environme } \\
\text { The two auditors are both } \\
\text { agency conducts audits (fina } \\
\text { services board, Bank of Indo } \\
\text { Indonesia's legislative bodie } \\
\text { agency that reports to the Pr }\end{array}$ & $\begin{array}{l}\text { laudits, performance audi } \\
\text { ia, legislative bodies, and c }\end{array}$ & $\begin{array}{l}\text { The principle difference between them involves reporting lines. The State Auditor is an independent public } \\
\text { pecial purpose audits) of all public offices (Central and local government, state-owned enterprises, public } \\
\text { dies that manage state finances), including those who are related to the forest sector, and reports to } \\
\text { Perwakilan Daerah). In contrast, the Board of Finance and Development Supervision is as a non-department } \\
\text { ation of the state budget and activities under the Executive branch. Both agencies support law enforcement }\end{array}$ \\
\hline
\end{tabular}




\subsection{Types of ecosystem goods and services}

Legislation principally covers goods and services related to provisioning and regulating services, and some (limited) supporting and cultural services (cf. MEA 2005). Using the terminology of the legislation itself, these reflect 6 categories (Table 3, Appendix).

Table 3. Checklist of ecosystem goods and services valued in legislation of seven government agencies

\begin{tabular}{|c|c|c|c|c|c|c|}
\hline Agencies & Timber & Water & Carbon & NTFPs ${ }^{*}$ & Tourism & Biodiversity \\
\hline Min. Forestry & X & X & & X & X & X \\
\hline Min. Environment & $\mathrm{X}$ & $\mathrm{X}$ & $\mathrm{X}$ & $\mathrm{X}$ & $\mathrm{X}$ & $\mathrm{X}$ \\
\hline Min. Finance & $\mathrm{X}$ & $\mathrm{X}$ & $\mathrm{X}$ & $\mathrm{X}$ & $\mathrm{X}$ & $\mathrm{X}$ \\
\hline State Auditor & $\mathrm{X}$ & & & & & \\
\hline $\begin{array}{l}\text { Board of } \\
\text { Supervision }\end{array}$ & $\mathrm{X}$ & & & & & \\
\hline $\begin{array}{l}\text { Central Statistics } \\
\text { Burea*** }\end{array}$ & $\mathrm{X}$ & $\begin{array}{c}\text { X } \\
\text { (underway) }\end{array}$ & & & & \\
\hline $\begin{array}{l}\text { Min. Natl. Dev. } \\
\text { Plan.* }\end{array}$ & $\mathrm{X}$ & $\begin{array}{c}\mathrm{X} \\
\text { (underway) }\end{array}$ & & & & \\
\hline \multicolumn{7}{|c|}{$\begin{array}{l}\text { Non-timber forest products } \\
\text { *** Agencies without specific subsidiary legislation. In cooperation with the WAVES Programme, they } \\
\text { will begin to update their accounting practices to follow the latest System of Environmental and } \\
\text { Economic Accounting (SEEA 2012), and will begin a programme to address a sub-set of goods and } \\
\text { services, notably land accounts (including forests) and trialing of national water accounts (water } \\
\text { services). }\end{array}$} \\
\hline
\end{tabular}

Timber is valued (as a provisioning service) across all agencies, while other goods and services are only valued by some agencies. Notably, bodies with cross-agency mandates (State Auditor, Board of Supervision, Statistic Agency) have comparatively narrow scopes (Table 3). Although these agencies are mandated to follow the subsidiary legislation of other agencies, to help them uphold their mandates (Table 1; Appendix), this is only done for timber (based on evidence from the focus group and available documents). In this respect, the Ministry of Finance stands out for its broad approach to valuation.

Legislation also varies in its terminology, scope and levels of clarity. For example, while four key pieces of legislation specifically address water, these actually refer to a wide range of supporting, provisioning and regulating services, ranging from direct use of water resources for commercial purposes, to household use, to flood protection, and to a wide range of general but unspecified services (Table 4).

Similarly, there is little consistency in how biodiversity is considered; in some legislation it is valued as a generic good or as part of a generic stock of valuable genetic resources (akin to a supporting service), while in others, valuation is restricted to specific rare species (associated with cultural services) or to species that can be legally utilized (provisioning services) (Appendix). While all of the studied agencies value timber, approaches to defining this resource vary considerably. For example, some include specifications that define timber into different categories, such as distinguishing trees for charcoal versus those for timber (Min. Finance), whilst others only recognize the value of specific hardwood species (Central Statistics Bureau). 
Table 4. Water-based goods and services across Indonesian legislation

\begin{tabular}{ll}
\hline Regulation & Definition \\
\hline $\begin{array}{l}\text { Government Regulation no. } \\
\text { 12 of 2014 }\end{array}$ & $\begin{array}{l}\text { Commercial water use within conservation forests, both direct } \\
\text { consumptive use and hydroelectric power generation }\end{array}$ \\
\hline $\begin{array}{l}\text { Ministry of Environment } \\
\text { Regulation no. 7 of 2014 }\end{array}$ & $\begin{array}{l}\text { Water flow regulation, erosion control, and direct consumptive } \\
\text { use }\end{array}$ \\
\hline $\begin{array}{l}\text { Ministry of Environment } \\
\begin{array}{l}\text { Regulation no. 14 and no. } \\
15 \text { of 2012 }\end{array}\end{array}$ & $\begin{array}{l}\text { Flood protection and "water flow" services (unspecified) in } \\
\text { state forest lands }\end{array}$ \\
\hline $\begin{array}{l}\text { Ministry of Finance } \\
\text { Guidelines for valuation of } \\
\text { natural resources 2008 }\end{array}$ & $\begin{array}{l}\text { Direct consumptive use of water service (unspecified) and } \\
\text { general hydrological services (unspecified) within protection } \\
\text { forests }\end{array}$ \\
\hline
\end{tabular}

Non-material, non-market and non-use goods and services, including those with intrinsic, cultural, educational, scientific or historical values, are not widely recognized in the reviewed legislation. Notable exceptions are the reference to Willingness to Pay for biodiversity, and the valuation of tourism as a cultural service (Table 3).

\subsection{Monetary valuation methods}

Across agencies, valuation methods vary considerably. Methods include the use of market price to determine value, use of government default values, willingness to pay, and cost of restoration (Appendix). This heterogeneity reflects the diversity of legislation objectives (Table 2), as not all methods are appropriate in all cases. However, it also points to inconsistencies across legislation, including in how these values are understood (e.g., Table 4) and in the different choices of methods, even for the same good or service (e.g., Table 5). For example, different agencies use different markets for determining timber values (e.g., local market, national market, government default price, Table 5). Similarly, the Ministry of Finance uses different valuation approaches for mangrove forests, employing a market price approach to value trees yielding timber and woodchips, and a production cost approach to value trees for charcoal (Table 5). 
Table 5. Heterogeneity in the valuation of timber across government agencies.

\begin{tabular}{|c|c|c|c|}
\hline Agency & Timber stocks considered in legislation & $\begin{array}{l}\text { Valuation } \\
\text { approach }\end{array}$ & Valuation \\
\hline Min. Finance & $\begin{array}{l}\text { Charcoal from mangrove forests } \\
\text { designated as production forests }\end{array}$ & Production cost & $\begin{array}{l}\text { Costs of extraction and processing into charcoal (e.g., raw materials, } \\
\text { labor, equipment and supplies, and maintenance, based on local survey) }\end{array}$ \\
\hline Min. Finance & $\begin{array}{l}\text { Woodchips from mangrove forests } \\
\text { designated as production forests }\end{array}$ & Market price & $\begin{array}{l}\text { Potential harvest volume per hectare } * \text { total mangrove forest area } * \text { local } \\
\text { market price }\end{array}$ \\
\hline Min. Finance & Timber from production forests & Market price & $\begin{array}{l}\text { Forest area } * \text { potential harvest volume (based on purposive field sampling } \\
\text { of trees }>30 \mathrm{~cm} \mathrm{DBH}) * \text { local market price (based on the survey of local } \\
\text { wood depot) }\end{array}$ \\
\hline Min. Forestry & $\begin{array}{l}\text { Timber within production forest } \\
\text { concessions }\end{array}$ & $\begin{array}{l}\text { Reference price } \\
\text { (price per unit, } \\
\text { tax rate) }\end{array}$ & $\begin{array}{l}\text { Timber volume (from production or transport report) } * \text { reference price } * \\
\text { taxes (Resource Rent Provision, Reforestation Fund)^ }\end{array}$ \\
\hline $\begin{array}{l}\text { Supreme Audit } \\
\text { Agency, Board } \\
\text { Fin. Dev. } \\
\text { Supervision, } \\
\text { Min. Natl. Dev. } \\
\text { Plan. }\end{array}$ & Timber on state forest land & $\begin{array}{l}\text { Reference price } \\
\text { (price per unit, } \\
\text { tax rate) }\end{array}$ & 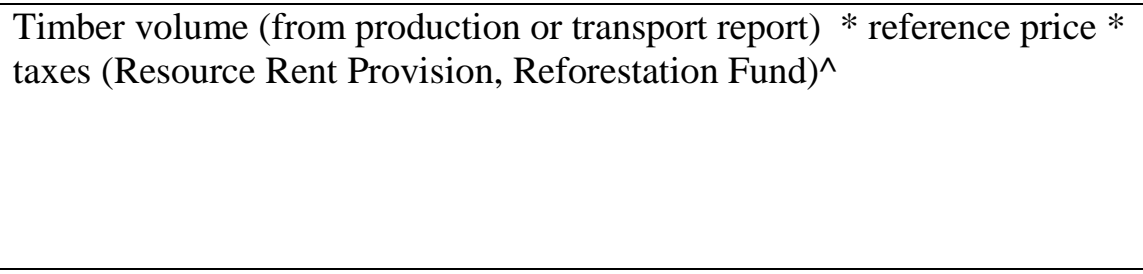 \\
\hline $\begin{array}{l}\text { Central } \\
\text { Statistics } \\
\text { Bureau }\end{array}$ & $\begin{array}{l}\text { Timber from production forests, } \\
\text { restricted to certain types of species: } \\
\text { teak in Java, and for "mix hardwoods" } \\
\text { in Java and select outer islands. }\end{array}$ & Market price & $\begin{array}{l}\text { Net present value in local market (based on the number of years until } \\
\text { maturity and a discount factor) * timber stock (from Min. Forest report of } \\
\text { national stocks) }\end{array}$ \\
\hline Min. Environ. & Timber from production forests & Market price & $\begin{array}{l}\text { Local market price - extraction cost - normal profit (assumed } 15 \% \text { return } \\
\text { on investment) * stock estimate (based on survey or GIS evaluation) }\end{array}$ \\
\hline Min. Environ. & Timber on any land & Restoration cost & $\begin{array}{l}\text { Actual cost of restoration (replanting and associated costs such as } \\
\text { transport and compost) }+ \text { site maintenance cost }\end{array}$ \\
\hline \multicolumn{4}{|c|}{$\begin{array}{l}\text { A Reference prices for timer have historically been managed by the Ministry of Trade, and were last updated in } 2012 \text { (Ministry of Trade number } 12 / \mathrm{M}-\mathrm{DAG} / \mathrm{PER} / 3 / 2012 \\
\text { on Stipulation of Reference Price for Forest Products to Calculate the Forest Product Provision Tax). Starting in 2014, responsibility for setting the reference price was } \\
\text { moved to the Ministry of Forestry Regulation P68/Menhut-II/2014 on Determination of Reference Prices for the Calculation of Forest Resource Provision, Compensation } \\
\text { of Stand Value and Replacement of Tree Stand }\end{array}$} \\
\hline
\end{tabular}




\section{Discussion}

An analysis of Indonesian legislation highlights the need to think actively about the mechanics of how valuation is institutionalized by government agencies (Fig. 1). It requires a critical, yet pragmatic interrogation of the technical nuances of valuation, alongside broader questions about the roles it plays in environmental governance.

Legislation identifies (Table 3) and defines (Table 4) a range of goods and services, and diverse approaches to valuation (e.g. Table 5) and to using this data in different contexts and at different levels of government (Table 2). This diversity is illustrated in the valuation of an Indonesian tree (Fig. 2). Valuation in an illegal logging case to estimate environmental harm would result in one set of monetary values. A natural capital accounting exercise would yield different values, and, if taxed by the Forest Department or valued during a state audit, values would be different again. In some cases these differences reflect diverse remits and methods tailored to those specific situations, which are non-comparable. In other cases, they indicate a highly polycentric governance arrangement across which there are inconsistences in definitions, methods and application. We discuss the Indonesian experience to consider the challenges associated with institutionalizing valuation into diverse government agencies. These include challenges of 1) defining which goods and services are/are not labeled as valuable; 2) selecting valuation methods; 3) identifying policy objectives for conducting valuation in different contexts, and 4) codifying and fixing values.

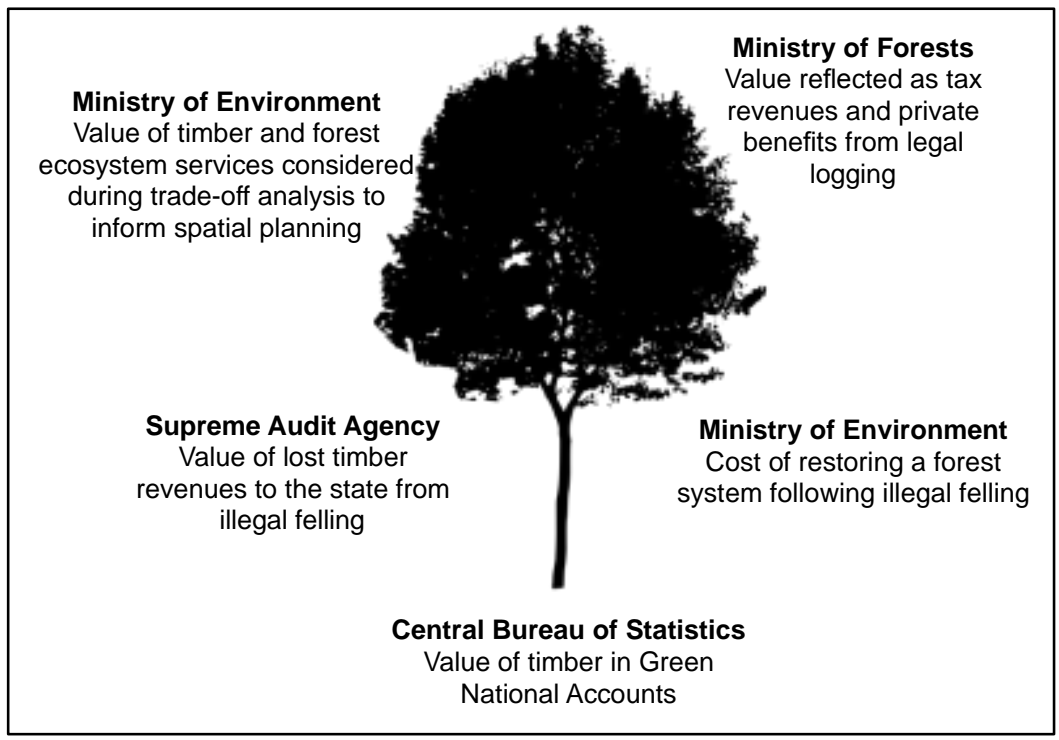

Figure 2. What is the value of an Indonesian tree? The economic value of an Indonesian tree in Indonesia varies across agencies and objectives.

\subsection{What is (and isn't) valuable}

Across the 7 agencies, legislation values a limited set of goods and services, focused on those that are marketable (Table 3), particularly timber (Table 5). This contrasts with the treatment of non-market and non-material services, which are largely overlooked (see critiques in Gómez-Baggethun and Ruiz-Pèrez 2011; Chan et al. 2012, 2016). The only cultural and amenity service explicitly valued is tourism, although the related industry also represents one of the countries largest, and growing, economic sectors (WB 2015). 
Critically, while more than 50 million Indonesians depend on open access to ecosystem services for food, shelter, building materials, livelihoods and other basic needs (UNEP and UNORCID, 2015), many related goods and services are absent from legislation (Table 3). Marketable non-timber forest products are the exception, as these are included in some pieces of legislation (Appendix). Although a broader suite of goods and services, including those important to culture and livelihoods, are acknowledged in some primary legislation (e.g., Law No 41 of 1999 on Forestry), none of the subsidiary legislation articulates the related methods, datasets, or policy objectives (Appendix). This highlights the challenge of moving from general principles (e.g., the right to a healthy environment, recognition of indigenous rights), to operationalizable actions grounded in legislation.

As a result, these goods and services are not officially recognized in ways that would allow for their equal consideration at policy-level, alongside others that are explicitly measured, valued and expressed in monetary terms. This is true even of agencies that apply a "total economic valuation" approach, yet overlook key types of goods and services (Appendix). While some argue that these types of values should not be monetized (e.g., Kallis et al. 2013), the structural oversight of certain types of values and human-environment relations has direct social implications; where government processes draw on valuation to make decisions on land rights, land and resource allocation, taxation or compensation, these will fail to address many constituents' core priorities.

There is growing recognition that decisions about valuation are active and political (Gómez-Baggethun and Pérez-Ruiz 2011; Kallis et al. 2013; Phelps et al. 2014; Kull et al. 2015). Decisions about what and how goods and services are (or are not) valued forms part of a broader policy debate imbued with the politics and power dynamics of knowledge production and policy making (Norgaard 2010; Jordan and Russel 2014; Berbés-Blázquez et al. 2016). This is true in Indonesia, where decisions about land and resources are uniquely politicized and often linked to corruption and mismanagement (see Ascher 1998; Smith et al. 2003; Barr et al. 2010; HRW 2013). For example, the focus on timber in legislation (Table 4) pre-dates ecosystem services concepts and derives from a history of colonial and political elite engaging in commercial timber extraction (Peluso 1991; Ross 2001). This is reflected in the Central Statistic Bureau, which recognizes the monetary value of only a few hardwood timber species on the island of Java in their accounting; other types of trees, locations and contexts (e.g. smallholder plantations) are excluded.

The political nature of valuation should not be underestimated; efforts to challenge the status quo, such as by increasing taxes, restricting industry, prosecuting powerful actors, or better recognizing the interests of marginalized communities, would confront established vested interests. Moreover, the use of valuation tools that make traditionally non-market goods and services monetarily valuable may create new tensions (cf. Phelps et al. 2010; Kallis et al. 2013), particularly in the context of competition among Indonesian government agencies (see Ascher 1998; Barr et al. 2010).

\subsection{Technical challenges shape valuation}

Indonesian legislation also reflects the technical challenges and pragmatic 
considerations of valuation. Legislation and guidelines must be clear to ensure that they are both credible and applicable (see Cowan and Foray 1997; Karieva et al. 2015). This is challenging in the context of baseline data limitations, complex tropical ecosystems, and where human and financial resources are lacking to conduct expensive studies. Moreover, the skills needed to operationalize environmental valuation are often under-represented in government agencies (e.g., Ministry of Finance; Jones et al. 2015).

Much of the reviewed legislation is hard to operationalize due to cryptic or conflicting guidelines and definitions (e.g., Table 4); incomplete, contradictory or inaccurate methods (Table 5); outdated default values (e.g., carbon, biodiversity, Appendix), and potential double counting (Appendix). Moreover, valuation can involve complex conceptual methods (e.g., contingent valuation, valuation of cultural services and other relational values, value transfer, option values, future values, valuation of wildlife, biodiversity and non-timber forest products; e.g., Spash 2008; Nijkamp et al. 2008; UNEP and UNORCID 2015; Appendix). There is a need to ensure that valuation guidelines and tools are clear, comprehensive and accessible, to ensure valuation does not marginalize stakeholders and agencies that cannot conduct, understand or use related tools and data (see Fry 2011).

Previous efforts to overcome these technical barriers offer useful lessons. For example, some legislation also draws on rapid surveys of local markets to facilitate more locally relevant, current valuation data (e.g., for timber, non-timber forest products; Table 5). Ministry of Environment legislation has provisions for nonmarketable and hard-to-measure services, using fixed default values for biodiversity, genetic resources and water services (Annex). Such "benefit transfer" techniques (Kubisweski et al, 2013) could help to overcome key technical and data limitations, such as to inform civil liability cases for environmental harm (Phelps et al. 2015). However, these approaches are nevertheless subject to great limitations (e.g. Brower 2000; Nelson and Kennedy 2009; Johnston and Rosenberger 2010; Phelps et al. 2014), as is the monetary valuation of cultural and relational values (Chan et al. 2016).

\subsection{Objectives of conducting valuation}

There are growing calls for a critical reflection of valuation practices (Kallis et al. 2013; Garmendia and Pascual 2013; Adams 2014), and for considering the various ways in which valuation can inform environmental governance (Phelps et al. 2015; Polasky et al. 2015; Kareiva et al. 2015; Jones et al. 2015).

Indonesian legislation reveals diverse arrangements and uses for valuation data, (see Fig. 1), including non-economic uses, such as to aid in decision-making analyses, as well as for liability for environmental harm and taxation-aspects that are often overlooked in the literature. Strategies also differ across agency mandates, jurisdictions (e.g. over mangroves versus other forest categories) and land use categories (e.g., production forest vs. state forest). However, most of the legislation is not specific about its policy objectives. For example, several documents refer to natural capital and state asset accounting (Appendix), but do not explain why this data should be collected and used. Similarly, valuation to inform spatial planning is referenced, but without guidance on the situations or processes under which this might be appropriate. 
Such gaps and distinctions in valuation approaches reflect both differences in objectives, as well as inadequate specificity, clarity and/or harmonization. There are cases where greater consistency among agencies is probably necessary. Taxation of natural resources, for example, is restricted to a narrow range of goods and services (Table 3). The valuation of timber stocks also varies across agencies (Table 5). Similarly, accounting of natural resource stocks by the two state audit agencies overlook the majority of goods and services, even those valued by other agencies (Table 4). Efforts to calculate natural capital costs are also largely disconnected from efforts to inform liability from environmental harm (e.g., Table 4; WAVES 2014).

Despite calls for clearer objectives and streamlined valuation guidelines (see Phelps et al. 2014), different uses require different types of data, values, spatial scales and levels of precision (Costanza et al. 2014). The aggregate and regional values often associated with national stock assessments, for example, do not automatically apply to specific local policy analysis or valuation for environmental harm. Moreover, stakeholders at different scales often attach different values to ecosystem services, which remain weakly reflected in policy (Heine et al. 2006). Greater clarity on which are appropriate to different agencies and uses is important, especially if nonspecialists operationalize valuation.

\subsection{Tensions to fixing valuation}

The US decision to mandate accounting of natural capital stocks within all federal planning and decision-making (USA 2015) reflects a trend towards greater formalization of valuation into government decision-making. While there are limitations to dictating exactly how valuation must be calculated and used, there is a need for greater clarity in how valuation is codified in legislation.

Stated policies often fail to materialize in practice in Indonesia (e.g., McCarthy et al. 2012; Anderson et al. 2016); if underlying legislation is not comprehensible, harmonized or logical, there is little hope it will be effectively operationalized. Coherence across legislation is important within the civil law tradition (Eskridge 1989), particularly given the complex hierarchy of Indonesian regulations and crossjurisdictional challenges associated with decentralized governance (see Ardiansyah and Jotzo 2013; Suwarno et al. 2015; Anderson et al. 2016). In its absence, disagreements over valuation have already emerged between civil society and government (e.g., over state loss calculations, MAPPI 2009). Disagreements can also play out in court disputes (Robertson and Wainwright 2015; Jones et al. 2015), and can limit the participation of some agencies. For example, forest carbon is increasingly central to Indonesian environmental policy (e.g., Astuti and McGregor 2015), but this is not fully reflected across governing legislation (Table 3 ).

However, once introduced, technical choices about methods, datasets and definitions can become fixed. For example, despite dynamic timber markets, many Indonesian agencies rely on fixed (or infrequently updated) default values (Appendix). Default values (e.g., dollars/hectare) for biodiversity, carbon and genetic resources are also fixed in legislation but are outdated and incomplete (Appendix). Similarly, some legislation fixes definitions and formulas that are not necessarily accurate, comprehensive or usable--but which are cumbersome to change (e.g., Table 4). 
Ways of thinking can similarly become entrenched, reinforcing certain frames for thinking about the environment (Vatn 2005; Gasparatos 2010; Lakoff 2010;

Robertson and Wainwright 2015). Notably, Indonesian legislation frames value as linked to price (Robertson and Wainwright 2015), with particular focus on market potential (e.g., timber, water, carbon stocks, Table 3 ).. This potentially imposes specific types of human-environment relations on communities that, in many cases, may operate using different value-sets and within different (largely non-monetized) economies. The reduction of complex environmental values into simple monetary values may serve certain policy objectives, but may fail to address other needs that skew decision-making (Martinez-Alier 2008), and leave little scope for envisioning alternative forms of governance (see Wainwright and Mann 2013). However, the exclusion of many goods and services from monetary valuation exercises may mean that they ultimately hold a lesser place in policy arenas dominated by economistic thinking.

\section{Conclusion}

Beyond the many limitations inherent to valuation (e.g., Chaisson 2002; Garmendia and Pascual 2013; Robertson and Wainwright 2015), we contend that frustration with valuation tools also results from a tendency to overlook key institutional dimensions the mechanics - that determine how it is incorporated into decision-making. Legislation provides a valuable window for unpacking the policy black box (Fig. 1), to unlock the potential of valuation in ways that promote positive environmental and social outcomes, and militate against undesirable impacts. Our analysis suggests that this requires 1) technocratic 'solutions' to address key gaps in legislation; 2) different and broader ways of thinking about valuation as a tool; 3) changed institutional arrangements to account for common assets, and 4) future research on how valuation is perceived and practiced. We highlight opportunities, both within Indonesia and internationally, to overcome these challenges.

The status of Indonesian legislation currently limits the utility of valuation tools. This requires some technocratic interventions, including review of the goods/services valued and related technical guidelines, to ensure clarity, data availability and usability. Moreover, environmental accounting can be costly, and requires new investment, such as through the WAVES initiative. "Benefit transfer" techniques (Kubisweski et al. 2013) are increasingly applied to reduce financial burdens and fill data gaps (see Nelson and Kennedy 2009); these may have a role to play in Indonesia. International efforts to account better for ecosystem complexity and hard-to-measure values (e.g., Chan et al. 2012; Diaz et al. 2015; Pastur et al. 2016) are pressing platforms such as WAVES and IPBES to provide both useable technical guidance and thought-leadership to their member countries.

The review also highlights the need to think more deeply about the policy objectives different stakeholders have for conducting valuation, particularly given the number of stakeholders involved across scales of governance. "Theory of Change" tools developed for program evaluation and planning (see Breast 2010) could help disentangle the processes behind Figure 1, and help stakeholders think through the pathways they expect - and want-valuation to inform environmental governance. This unpacking requires efforts to demonstrate and align the logic for gathering and using valuation data, and specify the circumstances under which different approaches 
are most appropriate (cf. Kallis et al. 2013). This is critical, as much of the reviewed legislation is cryptic about its policy objectives, while much of the literature automatically associates valuation with commoditization. This review reiterates that the use of monetary units does not necessarily mean that these become private commodities for trade (cf. Costanza et al 2014). Despite the existence of PES schemes in Indonesia, valuation for price setting is not focal to Indonesian legislation (Annex), which actually speaks to a broader range of policy objectives for valuation. This includes policy uses that are generally overlooked in the valuation literature, notably valuation to measure damages in legal suits over liability for environmental harm, which may represent an important frontier (White and Heckenberg 2011; Phelps et al. 2015; Jones et al. 2015).

A broadened view of valuation might also consider its role as a boundary object for exploring larger issues within environmental governance (Suwarno et al. 2015; Kallis et al. 2013; Clark et al. 2011). Discussion about monetary valuation presents opportunities to engage diverse communities in conversations, not only about specific policy choices based on relative monetary values, but also about different types of values, relationships, priorities, and participation. This reflects the clear, if surprisingly under-exploited opportunity, to integrate environmental, economic and political ecology (Kallis et al. 2013). Ecosystem services research increasingly highlights the need to integrate multiple forms of knowledge - including new strategies and methods to engage stakeholders, diverse value and knowledge systems, and different scales of organization (Chan et al. 2012; Kelemen et al. 2015). Importantly, this is also seeking ways to integrate non-monetary approaches into the mainstream (Limburg et al. 2002; Farley 2008; Garmendia and Pascual 2013). There is little evidence of valuation serving as this type of entry-point within Indonesia, but similar efforts are emerging in some mainstream international debates, with IPBES developing new guidelines for conducting valuation that extends beyond traditional, narrow concepts of provisioning services (Diaz et al. 2015).

These developments reflect the view that "many eco-services are best considered public goods or common pool resources, so conventional markets are often not the best institutional frameworks to manage them" (Costanza et al. 2014). This does not mean that valuation tools are irrelevant, but rather highlights the need for alternative or hybrid institutional arrangements that better account for diverse values (Costanza et al. 2014; Farley et al. 2015). For example, civil liability cases for environmental harm lever valuation data to enable restoration and to compensate the victims of environmental harm-measures that are being pioneered in Indonesia (see Jones et al. 2015). Other institutional arrangements, such as common assets trusts, also draw on valuation data, but to inform decisions via third sector governance arrangements; these trusts manage parts of the environment as common pool resources, via a board of trustees, on behalf of the beneficiaries (e.g., Vermont Common Assets Trust, Farley et al. 2015). Such systems already exist in parts of Indonesia, including Bali's long-standing collective subak (irrigation society) management of rice paddies and their irrigation (Geertz 1972).

There are several current policy windows through which to approach these discussions in Indonesia. Donor-driven initiatives are promoting valuation to inform policy and management, and have a central role to play in more critical thinking about how valuation can and should be used. For example, Indonesia's Ministry of National 
Development Planning (BAPPENAS) is collaborating with WAVES to establish natural capital accounts. This provides an opportunity to harmonize across agencies, particularly in the context of the 2014 merger of the Ministry of Environment and Forest Department, and also presents a chance to interrogate what kinds of goods and services are priorities and how/why their valuation is worthwhile. The One Map initiative, for example, provides a new platform for overlaying spatially explicit information that could include more on different types of monetary and non-monetary values. There is also scope to integrate valuation data into decisions related to mandatory sustainability standards (e.g., Indonesian Sustainable Palm Oil, Sustainable Production Forest Management). These types of analyses are important as valuation tools become increasingly popular across tropical developing countries, and parallel emerging international dialogue, such as through IPBES.

Future work must actively look beyond legislation, at its interactions with adjacent policies and instruments (e.g., land-use planning; permitting processing, mapping), including alignment between national and sub-national regulatory frameworks, and their actual implementation. This baseline review of legislation provides new insights, but an incomplete picture of policy as it is practiced; we did not evaluate how legislation has been operationalized because of a lack of baseline information and resources, and sensitivities within and across agencies. However, stated policies often differ from actual practices, so this exploration is important. Moreover, it is also a function of how bureaucrats understand, perceive and use valuation.

Bureaucrats charged with generating and utilizing valuation data, ranging from local decision-makers to judges, are central to the mechanics of governance. There is a clear need for research (and training) into their baseline understanding of ecosystems and valuation, their perceptions of what kinds of data are needed, and how (and whether) access to these types of information shape their thinking.

Faced with growing pressure to balance socio-economic and environmental objectives, valuation tools have emerged to the forefront of decision-making. However there is legitimate concern and frustration over their limitations, lack of demonstrable improved outcomes, and potential to yield unintended consequences. Improved, cautious deployment of these types of tools requires more astute understanding of how they are being understood, legislated and used by decisionmakers. Closer analysis of institutional mechanics is a critical step to overcoming the policy-practice rift between valuation tools and data and improved environmental governance.

\section{Acknowledgements}

This work was funded by the United Kingdom's DFID KnowFor grant to the Center for International Forestry Research. Thank you to Bernadetta Hariyanti for her work collecting and reviewing government documents, and to the 7 government agencies who participated and provided access to their information. Thank you to Kiran Asher for challenging, productive discussions; Christina Hicks for her comments, and Amy Collis for her edits. 


\section{References}

Adams, W.M. 2014. The value of valuing nature. Science 346, 549-551.

Anderson, Z.R., Kusters, K., McCarthy, J., Obidzinski, K. 2016. Green growth rhetoric versus reality: Insights from Indonesia. Glob. Environ. Chang. 38:30-40.

Ardiansyah, F., Jotzo, F. 2013. Decentralization and avoiding deforestation. In: Howes, S., Rao, M.G. (Eds.) Federal Reform Strategies: Lessons from Asia and Australia. Oxford University Press, Oxford.

(ADB) Asian Development Bank. 2013. Indonesia Water supply and sanitation sector assessment, strategy and road map. Asian Development Bank, Manila, Philippines. URL: http://www.adb.org/documents/indonesia-water-supply-and-sanitationsector-assessment-strategy-and-road-map.

Ascher, W. 1998. From oil to timber: The political economy of off-budget development financing in Indonesia. Indonesia 65, 37-61.

Astuti, R., McGregor, A. 2015. Governing carbon, transforming forest politics: A case study of Indonesia's REDD+ Task Force. Asia Pac. View. 56, 21-36.

Balvanera, P., Quijas, S., Martin-Lopez, B., Barrios, E., Dee, L., Isbell, F., Durance, I., White, P., Blanchard, R., de Groot, RS. 2016. The links between biodiversity and ecosystem services. Handbook of Ecosystem Services, Earthscan-Routledge.

Bateman, I.J., Coombes, E., Fitzherbert, E., Binner, A., Bad'ura, T., Carbone, C., Fisher, B., Naidoo, R., Watkinson, A.R. 2015. Conserving tropical biodiversity via market forces and spatial targeting. P. Natl. Acad. Sci.112,7408-7413.

Barbier, E.B., S. Sathiratai. 2004. Shrimp farming and mangrove loss in Thailand. Edgard Elgar, London.

Barr, C. Dermawan, A., Purnomo, H., Komarudin, H. 2010. Financial governance and Indonesia's Reforestation Fund during Soeharto and post-Soeharto periods, 19892009. A political economic analysis of lessons for REDD+. CIFOR Occasional Paper 52. Center for International Forestry Research (CIFOR), Bogor, Indonesia. URL: http://www.cifor.org/publications/pdf_files/OccPapers/OP-52.pdf.

(BPK) Badan Pemeriksa Keuangan. 2013. Temuan korupsi Sekitar Tambang. Warta BPK. URL: http://www.bpk.go.id/magazine/majalah-bpk.

Bateman, I.J., Harwood, A.R., Mace, G.M., Watson, R.T., Abson, D.J., Andrews, B., Binner, E., Crowe, A., et al. 2013. Bringing Ecosystem Services into Economic Decision-Making: Land Use in the United Kingdom. Science 341, 45-50.

Berbés-Blázquez, M. González, J., Pascual, U. 2016. Towards an ecosystem services approach that addresses social power relations. Current Opinion in Environmental Sustainability. 19. 134-143

Bille, R., Laurans, Y., Mermet, L., Pirard, R., Rankovic, A. 2012. Valuation without action? On the use of economic valuations of ecosystem services. Institut du Developpment Durable et des Relations Internationales Policy Brief 07/12, Paris.

Braat, L.C., de Groot, R. 2012. The ecosystem services agenda: Bridging the worlds of natural science and economics, conservation and development, and public and private policy. Ecosyst. Serv. 1: 4-15.

Brest, P. 2010. The Power of Theories of Change. Stanford Soc. Innov. Rev. Spring. Butler, R. 2015. Carbon emissions from Indonesia's peat fires exceed emissions from entire U.S. economy. 15 October 2015. URL: http://news.mongabay.com/2015/10/carbon-emissions-from-indonesias-peat-firesexceed-emissions-from-entire-u-s-economy/

Brouwer, R., 2000. Environmental value transfer: state of the art and future prospects. Ecol. Econ. 32, 137-152. 
Carpenter, S.R., Mooney, H.A., Agard, J., Capistrano, A., DeFries, R.S., Diaz, S., Dietz, T., Duraiappah, A.K. et al. 2009. Science for managing ecosystem services: Beyond the Millennium Ecosystem Assessment. P. Natl. Acad. Sci. USA 106, 1305-1312.

Chaisson, E.J., 2002. Cosmic Evolution: The Rise of Complexity in Nature. Harvard University Press, Cambridge, MA.

Chan, K., Guerry, A.D., Balvanera, P., Klain, S., Satterfield, T., Basurto, X., Bostrom, A., Chuenpagdee, R. et al. 2012. Where are cultural and social in ecosystem services? A framework for constructive engagement. BioScience 62, 744-756.

Chan, K., Balvanera, P., Benessaiah, K., Chapman, M., Díaz, S., Gómez-Baggethun, E., Gould, R.K., Hannahs, N., et al., 2016. Why protect nature? Rethinking values and the environment. Proc. Nat. Acad. Sci 113, 1462-1465.

Clark, W.C., Tomich, T.P., van Noordwijk, M., Guston, D., Catacutan, D., Dickson, N.M. and McNie, E. 2011. Boundary work for sustainable development: natural resource management at the Consultative Group on International Agricultural Research (CGIAR). Proc. Nat. Acad. Sci., doi:10.1073/pnas.0900231108

Geertz, C. 1972. The wet and the dry: Traditional irrigation in Bali and Morocco. Human Ecol. 1, 23-39.

Costanza, R., Daly, H. 1992. Natural capital and sustainable development. Conserv. Biol. 6, 37-46.

Costanza, R., d'Arge, R., de Groot, R., Farber, S., Grasso, M., Hannon, B., Limburg, K., Naeem, S., et al., 1997. The value of the world's ecosystem services and natural capital. Nature 387, 253-260.

Costanza, R., de Groot, R., Sutton, P., van der Ploeg, S., Anderson, S.J., Kubiszewski, I., Faber, S., Turner, R.K. 2014. Changes in the global value of ecosystem services. Global Environmental Change 26:152-158.

Cowan, R., Foray, D. 1997. The economics of codification and the diffusion of knowledge. Ind. Corp. Chang. 6, 595-622.

Daily, G. 1997. Nature's Services: Societal Dependence on Natural Ecosystems. Island Press, Washington, D.C.

de Groot, R.S., Fisher, B., Christie, M., Aronson, J., Braat, L.C., Haines-Young, R., Gowdy, J., Maltby, E., et al., 2010. Integrating the ecological and economic dimensions in biodiversity and ecosystem service valuation. In: Kumar, P. (Ed.), TEEB Foundations 2010. The Economics of Ecosystems and Biodiversity (TEEB): Ecological and Economic Foundations. Earthscan, London.

Diaz, S., Demissew, S., Carabias, J., Joly, C., Lonsdale, M., Ash, N., Larigauderie, A., Adhikari, J.R. et al., 2015. The IPBES conceptual framework - connecting nature and people. Current Opinion in Enviorn. Sust. 14:1-16.

Eskridge Jr., W.N. 1989. Public values in statutory interpretation. Penn. Law Rev. 137, 1007-1104.

Etxano, I., Garmendia, E., Pascual, U., et al. 2015. A participatory integrated assessment approach for planning and managing Natura 2000 network. Environment And Planning C-Government And Policy. 33. 1207 - 1232.

Farley, J. 2008. The role of prices in conserving critical natural capital. Conserv. Biol. 22, 1399-1408.

Farley, J., R. Costanza, G. Flomenhoft, and D. Kirk. 2015. The Vermont Common Assets Trust: an Institution for Sustainable, Just and Efficient Resource Allocation. Ecological Economics 109:71-79 
Ferraro, P.J., Kiss A. 2002. Direct payments to conserve biodiversity. Science 298, 1718-1719.

Fisher, B., Turner, K., Zylstra, M., Brouwer, R., de Groot, R., Farber, S., Ferraro, P., Green, R. et al. 2008. Ecosystem services and economic theory: Integration for policy-relevant research. Ecol. Appl. 18, 2050-2067.

Ferraro, P., and A. Kiss. 2002. Direct payments to conserve biodiversity. Science 298, 1718-1719

Ferraro, P.J., Lawlory, K., Mullanz, K.L., Pattanayak, S.K. 2012. Forest figures: ecosystem services valuation and policy evaluation in developing countries. Rev. of Environ. Econ. \& Pol. 6, 20-44

Folke, C. 2006. The economic perspective: Conservation against development versus conservation for development. Conservation Biology 20:686-688.

Fry, B.P. 2011. Community forest monitoring in REDD+: the 'M' in MRV? Enviorn. Sci. \& Pol. 14, 181-187.

Garmendia, E, Pascual, U. 2013. A justice critique of environmental valuation for ecosystem governance. Pages161-186 in T Sikor, The justices and injustices of ecosystem services. Earthscan, London.

Garmendia, E., Apostolopoulou, E., Adams,W.M., Bormpoudakis, D. 2016. Biodiversity and Green Infrastructure in Europe: boundary object or ecological trap?. Land Use Policy 56, 315-319.

Gasparatos, A. 2010. Embedded value systems in sustainability assessment tools and their implications. J. Environ. Manage. 91, 1613-1622.

Gómez-Baggethun, E., Pérez-Ruiz, M. 2011. Economic valuation and the commodification of ecosystem services. Prog. Phys. Geog. 35, 613-628.

Guerry, A.D., Polasky, S., Lubchenco, J., Chaplin-Kramer, R., Daily, G.C., Griffin, R., Ruckelshause, M., Bateman, I.J., et al., 2015. Natural capital and ecosystem services informing decisions: From promise to practice. P. Natl. Sci. Acad. USA $112,7348-7355$.

Hein, L., van Koppen, K., de Groot, R.S., van Ierland, E.C. 2006. Spatial scales, stakeholders and the valuation of ecosystem services. Ecological Economics 57, 209-228.

Hull, M.S. 2012. Documents and bureaucracy. Ann. Rev. Anthropol. 41, 251-267.

(HRW) Human Rights Watch. 2009. Wild money, The human rights consequences of illegal logging and corruption in Indonesia's forestry sector. Human Rights Watch, New York. URL: http://www.hrw.org/reports/2009/12/01/wildmoney-0.

(HRW) Human Rights Watch. 2013. The dark side of green growth: The human rights impacts of weak governance in Indonesia's forestry sector. Human Rights Watch, New York. URL: https://www.hrw.org/report/2013/07/15/dark-side-greengrowth/human-rights-impacts-weak-governance-indonesias-forestry.

Hussai, S., Gundimeda, H. 2010. Tools for Valuation and Appraisal of Ecosystem Services in Policy Making. In: The Economics of Ecosystem and Biodiversity for Local and Regional Policy Makers. Earthscan, London.

Irawan, S., Tacconi, L., Ring, I. 2014. Designing intergovernmental fiscal transfers for conservation: The case of REDD+ revenue distribution to local governments in Indonesia. Land Use Policy 36, 47-59.

Johnston, R.J., Rosenberger, R.S., 2010. Methods, trends and controversies in contemporary benefit transfer. J. Econ. Surv. 24, 479-510.

Jones, C.A., Pendergrass, J., Broderick, J., Phelps, J. 2015. Tropical conservation and liability for environmental harm. Environ. Law Rev. 45, 11032-11050. 
Jordan, A., Russel, D. 2014. Embedding the concept of ecosystem services? The utilisation of ecological knowledge in different policy venues. Environ. Plann. C: Gov. \& Pol. 32, 192-207.

Kallis, G., Gómez-Baggethun, E., Zografos, C. 2013. To value or not to value? That is not the question. Ecol. Econ. 94, 97-105.

Kareiva, P.M., McNally, B.W., McCormick, S., Miller, T., Ruckelshause, M. 2015. Improving global environmental management with standard corporate reporting. $\mathrm{P}$ Natl. Acad. Sci. USA 112, 7375-7382.

Kelemen, E., Barton, D., Jacobs, S., Martín-López, B., Saarikoski, H., Termansen, M., Bela, G., Braat, L. et al. 2015. Preliminary guidelines for integrated assessment and valuation of ecosystem services in specific policy contexts. EU FP7 OpenNESS Project Deliverable 4.3., European Commission FP7.

Kubiszewski, I., Costanza, R., Franco, C., Lawn, P., Talberth, J., Jackson, T., Aylmer, C., 2013. Beyond GDP: measuring and achieving global genuine progress. Ecol. Econ. 93, 57-68.

Kull, C.A., de Sartre, X.A., Castro-Larranaga, M. 2015. The political ecology of ecosystem services. Geoforum 61, 122-134.

Lakoff, G. 2010. Why it matters how we frame the environment. Environ. Comm. 4, 70-81

Laurans, Y., Mermet, L. 2014. Ecosystem services economic valuation, decisionsupport system or advocacy? Ecosyst. Serv. 7, 98-105.

Leimona, B., Lusiana, B., van Noordwijk, M., Mulyoutami, E., Ekadinata, A., Amaruzaman, S. 2015. Boundary work: Knowledge co-production for negotiating payment for watershed services in Indonesia. Ecosyst. Serv 15, 4562.

Limburg, K. E., O’Neill, R. V, Costanza, R. and Farber, S. 2002. Complex systems and valuation. Ecol. Econ. 41, 409-20.

Loureiro, M. L., J. B. Loomis, and M. X. Vázquez. 2009. Economic valuation of environmental damages due to the Prestige Oil spill in Spain. Environmental and Res. Econ. 44, 537-553

(MAPPI) Masyarakat Pemantau Peradilan Indonesia. 2012. Case analysis of corruption case on permit in forestry sector, evaluation and legalization of annual working plan IUPHHK HT 12 industrial plant companies, 2005-2006, Riau Province. MAPPI, Fakultas Hukum, Universitas Indonesia, Jakarta, Indonesia.

Maron, M., Gordon, A., Mackey, B.G., Possingham, H.P., Watson, J.E.M. 2015. Conservation: Stop misuse of biodiversity offsets. Nature 523, 401-403.

Martinez-Alier, J. 2008. Languages of Valuation. Econ. Pol. Weekly 43, 28-32.

McAfee, K. 1999. Selling nature to save it? Biodiversity and the rise of green developmentalism. Environ and Plann. D 17, 133-54.

McAfee, K. 2015. Green economy and carbon markets for conservation and development: a critical view. Int. Environ. Agree. 2015, 1-21.

McCarthy, J.F., Vel, J.A.C., Afiff, S. 2012. Trajectories of land acquisition and enclosure: development schemes, virtual land grabs, and green acquisitions in Indonesia's Outer Islands. J. Peasant Stud 39, 521-549.

McCauley, D.J. 2006. Selling out on nature. Nature 443, 27-28

(MEA) Millennium Ecosystem Assessment. 2005. Ecosystems and human wellbeing: biodiversity synthesis. World Resources Institute, Washington, D.C. URL: http://www.millenniumassessment.org/en/Synthesis.html.

Muradian, R., Rival, L. 2012. Between markets and hierarchies: The challenge of governing ecosystem services. Ecosys. Serv. 1, 93-100. 
Muradian, R., Gómez-Baggethun, E., 2013. The institutional dimension of "marketbased instruments" for governing ecosystem services: introduction to the special issue. Soc. Nat. Resour. 26, 1113-1121.

Naeem, S. Naeem, S., Ingram, J.C., Varga, A., Agardy, T., Barten, P., Bennett, G., Bloomgarden, E., et al. 2015. Get the science right when paying for nature's services. Science 347, 1206-1207.

Nelson, J.P., Kennedy, P.E., 2009. The use (and abuse) of meta-analysis in environmental and natural resource economics: an assessment. Environ. Resour. Econ. 42, 345-377.

(NCP) The Natural Capital Project. 2015. InVEST in Practice. The Natural Capital Project, Stanford, CA. URL: http://www.naturalcapitalproject.org/policy_tools.html

Nijkamp, P., Vindigni, G., Nunes, P.A.L.D.. 2008. Economic valuation of biodiversity: A comparative study. Ecol. Econ. 67, 217-31.

Palomo, I., Felipe-Lusia, M.R., Bennett, E.M., Martin-Lopez, B., Pascual, U. 2016. Ecosystem service co-production. Handbook of Ecosystem Services. EarthscanRoutledge, London.

Pastur, G.M., Peri, P.L., Lencinas, M.V., Garcia-Llorente, M., Martin-Lopez, B. 2016. Spatial patterns of ecosystem services provision in Southern Patagonia. Landscape Ecol. doi: 10.1007/s10980-015-0254-9.

Pearce, D.W., Markandya, A., Barbier, E. 1989. Blueprint for a Green Economy. Earthscan, London.

Peluso, N.L. 1991. The history of state forest management in Colonial Java. Forest \& Conserv. Hist. 35, 65-75.

Phelps, J., Hariyanti, B., Sinaga, A.C., Dermawa, A. 2014. Environmental Valuation in Indonesia: Implication for forest policy, legal liability and state losses estimates. Center for International Forestry Research (CIFOR), Bogor, Indonesia. URL: http://www.cifor.org/library/5288/environmental-valuation-in-indonesiaimplication-for-forest-policy-legal-liability-and-state-losses-estimates/.

Phelps, J., Jones, C.A., Pendergrass, J.A., Erik, Gómez-Baggethun. 2015. Environmental liability: A missing use for ecosystem services valuation. P. Natl. Acad. Sci. USA 112, E5379.

Phelps, J., Webb, E.L., Agrawal, A. 2010. Does REDD+ threaten to recentralize forest governance? Science 328, 312-313

Polasky, S., Guerry, A.D., Lubchenco, J., Ruckelshaus, M. 2015. Liability rules provide incentives to protect natural capital. P. Natl. Acad. Sci. USA 112, E5380.

Ricketts, T., Daily, G., Ehrlich, P., Michener, C. 2004. Economic value of tropical forest to coffee production. P. Natl. Acad. Sci. USA 10, 12579-12661.

Robertson, M.M., Wainwright, J.D. 2015. The value of nature to society. Ann. Assoc. Am.Geog.103, 890-905.

Rodriguez-Labajos, B., Martinez-Alier, J. 2013. The economics of ecosystems and biodiversity: Recent instances for debate. Conserv. Soc. 11, 326-342.

Rosenthal, A., Verutes, G., McKenzie, E., Arkema, K.K., Bhagabati, N., Bremer, L.., Olwero, N., Vogl, A.L. 2014. Process matters: A framework for conducting decision-relevant assessments of ecosystem services. Int. J. Biod. Sci. Ecosyst. Serv. \& Manag. 11, 190-204.

Ross, M. L. 2001. Timber Booms and Institutional Breakdown in Southeast Asia. Cambridge University Press, Cambridge.

Ruckelhaus, M., McKenzie, E., Tallis, H., Guerry, A., Daily, G., Kareiva, P., Polasky, S., Ricketts, T., et al. 2013. Notes from the field: lessons learned from using 
ecosystem service approaches to inform real-world decisions. Ecol. Econ. 115, 1121.

Ruhl, J.B., Salzman, J., 2007. The law and policy beginnings of ecosystem services. J. Land Use 22, 157-172.

Sahide, M.A.K., Giessen, L. 2015. The fragmented land use administration in Indonesia--Analysing bureaucratic responsibilities influencing tropical rainforest transformation systems. Land Use Policy 43, 96-110.

Salzman, J., Ruhl, J.B. 2000. Currencies and the Commodification of Environmental Law. Stanford Law Rev. 53, 607-694.

Scharks, T., Masuda, Y.J. 2016. Valuing nature isn't evil. Conserv. Lett. doi: 10.1111/conl.12234.

Sills, E., Atmadja, S.S., de Sassi, C., Duchelle, A.E., Kweka, D.L., Resosudarmo, I.A.P., Sunderlin, W.D. (Eds.) 2014. REDD+ on the ground. Center for International Forestry Research (CIFOR), Bogor, Indonesia. URL: www.cifor.org/redd-case-book.

Silverton, J. 2015. Have ecosystem services been oversold? Trends Ecol. Evol. 30, 641-648.

Spash, C.L., 2008. Deliberative monetary valuation (DMV) and the evidence for a new value theory. Land Econ. 84, 469-488.

Spash, C.L. 2015. Bulldozing biodiversity: The economics of offsets and trading-in Nature. Biol. Conserv. 192, 541-551.

Suwarno, A., Hein, L., Sumarga, E. 2015. Governance, Decentralisation and Deforestation: The Case of Central Kalimantan Province, Indonesia. Q. J. Int. Ag. 54, 77-100.

TEEB (The Economics of Ecosystems and Biodiversity), 2010. The Economics of Ecosystems and Biodiversity: Ecological and Economic Foundations. Earthscan, London.

(UNEP) United Nations Environmental Programme and (UNORCID) United Nations Office for REDD+ Coordination in Indonesia (UNORCID). 2015. Forest ecosystem valuation study: Indonesia. Jakarta, Indonesia. URL:

http://www.unredd.net/index.php?option=com_content\&view=article\&id=2198:pu blication-launch-forest-ecosystem-valuation-study-forindonesia\&catid $=98 \&$ Itemid $=749$.

(USA) United States of America. 2015. Incorporating natural infrastructure and ecosystem services in federal decision-making. The White House, Washington, DC. URL: https://www.whitehouse.gov/blog/2015/10/07/incorporating-naturalinfrastructure-and-ecosystem-services-federal-decision-making.

Vatn, A. 2005. Rationality, institutions and environmental policy. Ecological Economics 55:203-217.

Vatn, A. 2006. Institutions and the Environment. Edward Elgar Publishing.

Vatn, A. 2009. An institutional analysis of methods for environmental appraisal. Ecol. Econ. 68, 2207-2215.

Waite, R., Burke, L., Gray, E. 2014. Coastal Capital, Ecosystem valuation for decision making in the Caribbean. World Resources Institute, Washington, D.C. URL: http://www.wri.org/publication/coastal-capital-guidebook.

Watson, R.T. 2005. Turning science into policy: challenges and experiences from the science policy interface. Philos. T. Roy. Soc. B 360,471-477.

(WAVES) Wealth Accounting and the Valuation of Ecosystem Services. 2015. WAVES Website. The World Bank, Washington, D.C. URL: www.wavespartnership.org. 
(WB) World Bank. 2015. International tourism, receipts. World Development Indicators, World Bank, Washington D.C. URL: http://data.worldbank.org/indicator/ST.INT.RCPT.CD.

(WBCSD) World Business Council for Sustainable Development. 2011. Guide to Corporate Ecosystem Valuation: A Framework for Improving Corporate Decisionmaking. URL: www.wbcsd.org/work-program/ecosystems/cev.aspx.

White R., Heckenberg D. 2011. Environmental horizon scanning and criminological theory and practice. Eur. J. Crim. Pol. Res. 17:87-100. 